\title{
Leczenie zespołu suchego oka za pomocą kwantowego rezonansu komórkowego
}

\author{
Biomolecular quantum resonance in the treatment of dry eye disease
}

Piotr Fryczkowski

Przychodnia i Szpital Okulistyczny Retina Dyrektor medyczny: dr n. med. Piotr Fryczkowski

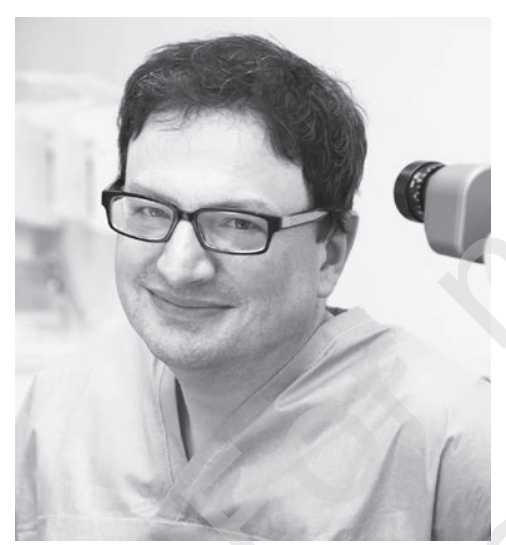

N A J W A Ż N IEJSZE

Wprowadzenie nowej technologii kwantowego rezonansu komórkowego w leczeniu choroby suchego oka może wpłynąć na poprawę wydzielania wszystkich gruczołów uczestniczących w produkcji łez.

\section{H I G H L I G H T S}

The introduction of new quantum cell resonance technology for the treatment of dry eye disease can improve the secretion of all glands involved in the production of tears.

\section{STRESZCZENIE}

Zrównoważenie składu łez, a co za tym idzie - przywrócenie homeostazy powierzchni oka jest trudne do osiągnięcia. Wpływają na to złożoność składu łez, różnorodność gruczołów wydzielniczych, a także skomplikowane i nie do końca poznane interakcje oddziałujące na skład, jakość i ilość łez. Zastosowanie technologii kwantowego rezonansu komórkowego - Biomolecular Quantum Resonance Rexon Eye ${ }^{\mathrm{TM}}$ (Resono Ophthalmic, Włochy) - opiera się na dostarczaniu kwantów (porcji) energii elektromagnetycznej wysokich częstotliwości (4-64 MHz) i niskich mocy, które wchodząc w interakcje z transportem jonów, białek błon komórkowych, a także oddziałując na same komórki, zmieniają ich działanie. Zastosowanie nowej technologii w leczeniu zespołu suchego oka dołącza do istniejących zastosowań kwantowego rezonansu komórkowego, takich jak: chirurgia, leczenie ran, leczenie złamań kości, a także leczenie bólu.

Słowa kluczowe: zespół suchego oka, kwantowy rezonans komórkowy

\section{ABSTRACT}

Balancing the composition of tears and, consequently, restoring the homeostasis of ocular surface, is difficult to achieve. This is due to the complex composition of tears, the variety of secretory glands involved, as well as complex and not fully understood interactions affecting the composition, quality, and quantity of tears. The application of Biomolecular Quantum Resonance technology Rexon Eye ${ }^{\mathrm{TM}}$ (Resono Ophthalmic, Italy) is based on providing quantum (portions) of high-frequency electromagnetic energy (4-64 MHz) at low power whose interaction with the transport of ions, proteins of cell membranes, and cells changes cell performance. The use of new technology in the treatment of dry eye syndrome combines existing applications of Biomolecular Quantum Resonance such as surgery, treatment of wounds, treatment of bone fractures, as well as treatment pain.

Key words: dry eye disease, biomolecular quantum resonance 


\section{WSTĘP}

Po raz pierwszy terminu suche oko użył Andre de Roth, w 1950 r. [1]. Od tego czasu nazwa ulegała zmianom poprzez zespót suchego oka, aż do obecnie używanego terminu choroba suchego oka (DED, dry eye disease). W $2007 \mathrm{r}$. DEWS (International Dry Eye Workshop) wprowadził trzystopniową klasyfikację w oparciu o etiologię, mechanizm i stopień zaawansowania choroby. Uważa się, że choroba suchego oka występuje u $8 \%$ populacji, z czego $78 \%$ stanowią kobiety.

Mimo tak powszechnego występowania możliwości terapeutyczne dotyczące choroby suchego oka są ograniczone i sprowadzają się zasadniczo do dwóch, wymienionych poniżej:

- nawilżania powierzchni oka kroplami, żelami lub maściami

- zatrzymywania łez poprzez zatkanie kanalików łzowych.

W cięższych przypadkach możliwe jest odbudowanie/ wzmocnienie powierzchni oka poprzez naszycie owodni czy zakraplanie kropli z osocza.

Poza uzupełnianiem składu łez możliwe jest wykonywanie zabiegów mających na celu pobudzenie do wydzielania gruczoły powiekowe Meiboma poprzez terapię IPL lub mechaniczne oczyszczanie gruczołów systemem LipiFlow ${ }^{\circ}$ (Abbot/Johnson \& Johnson). Najnowszą metodę stanowi wykorzystanie pola elektromagnetycznego w urządzeniu Rexon Eye ${ }^{\mathrm{TM}}$ (Resono Ophthalmic, Włochy).

Cel artykułu stanowią przegląd wiedzy dotyczącej zabiegów stosowanych w terapii choroby suchego oka oraz podzielenie się pierwszymi doświadczeniami z pracy z aparatem Rexon Eye ${ }^{\mathrm{TM}}$.

\section{ROLA GRUCZOŁÓW POWIEKOWYCH MEIBOMA}

Gruczoły zlokalizowane w powiekach opisał jako pierwszy, w 1666 r., niemiecki lekarz Heinrich Meibom. Liczba gruczołów jest osobniczo zmienna, ale zakłada się, że w powiece górnej znajduje się 25-50 gruczołów, podczas gdy w powiece dolnej - 20-30 [1, 2]. Gruczoły powiekowe Meiboma produkują oleistą wydzielinę, w której skład wchodzą mieszanina cholesterolu, wosków, estrów cholesterolu, fosfolipidów, a także niewielkie ilości triglicerydów [1, 3]. W normalnych warunkach gruczoły obu powiek zawierają ok. $300 \mu$ g wydzieliny.

Po każdym mrugnięciu wydzielina gruczołów jest rozprowadzana po powierzchni filmu łzowego, tworząc ochronną warstwę grubości ok. 20 do 160 nm chroniącą przed parowaniem pozostałą część filmu łzowego.

Rozprzestrzenianie się warstwy tłuszczowej filmu łzowego zaczyna się od powieki dolnej, przy czym stabilność war- stwy tłuszczowej ocenia się na 1-2 s. Przedłużone rozprzestrzenianie się warstwy tłuszczowej może być sygnałem zaburzenia wydzielania łez, dlatego ciągłość warstwy lipidowej ogranicza nadmierne łzawienie [4].

Uważa się, że niewydolność gruczołów powiekowych Meiboma odpowiada za ok. 50\% przypadków zespołu suchego oka $[3,5,6]$.

Pozostałe przypadki są wynikiem nieprawidłowości składu łez na wielu poziomach. Prawidłowy skład łez jest rezultatem skomplikowanych interakcji wielu gruczołów oka i jego aparatu ochronnego. Warstwę śluzową odpowiedzialną za utrzymywanie filmu łzowego na powierzchni rogówki produkują komórki kubkowe spojówki, gruczoły Henlego, Manza i komórki nabłonka rogówki oraz spojówki. Środkową najgrubszą warstwę wodną produkują gruczoły łzowe dodatkowe, Krausego i Wolfringa. Zewnętrzną tłuszczową warstwę chroniącą przed parowaniem, a także zapewniającą właściwe rozprowadzanie łez wydzielają głównie gruczoły Meiboma, Molla i Zeisa. Przez wiele dziesięcioleci skład łez pozostawał niezbadany, a większość lekarzy uważała, że za produkcję łez odpowiada tylko jeden gruczoł łzowy.

\section{ZABIEGI LASEROWE INTENSYWNYM PULSEM ŚWIATKA - IPL}

W 1996 r. FDA (Food and Drug Administration) dopuściła użycie lasera rubinowego $(694 \mathrm{~nm})$ do epilacji ciała. Od tego czasu w medycynie estetycznej i dermatologii wykorzystuje się lasery rubinowe (694 nm), aleksandrytowe (755 nm), diodowe (800 nm) i Nd:YAG (1064 nm, neodymium yttrium-aluminum-garnet). Osobną grupę stanowią lasery działajacce w szerokim zakresie fal 590-1200 nm, określane mianem zabiegów laserowych intensywnym pulsem światła (IPL, intensive pulsed light). Im wyższa długość fali, tym głębsza penetracja wiązki lasera. Warunkiem udanej termolizy jest absorpcja energii laserowej przez odpowiedni chromofor. W skórze chromoforami są melanina i oksyhemoglobina. Ze względu na głębokość penetracji lasera, obliczaną na 3-4 mm, energię lasera najbardziej absorbuje melanina cebulek włosowych skóry, w mniejszym stopniu oksyhemoglobina naczyń krwionośnych. Absorpcja energii laserowej umożliwia czasową lub trwałą koagulację powierzchownych naczyń krwionośnych skóry.

W przypadku użycia lasera IPL do stymulacji i oczyszczania gruczołów powiekowych Meiboma wykonuje się kilka pulsów laserowych [2-5] na brzegu kości czołowej w okolicy brwi i/lub na dolnym skraju oczodołu od strony kości jarzmowej i szczękowej po uprzednim zabezpieczeniu gałki ocznej specjalnymi osłonami [6, 7].

Należy podkreślić, że bezpieczeństwo zabiegu jest zależne od szczelnego osłonięcia oka. W przypadku przedostania się energii laserowej do oka opisywano przypadki zmian 
kształtu źrenicy, a także przesunięcia źrenicy (korektopia) bezpośrednio po zabiegu laserowej epilacji [8]. Ponadto stwierdzono atrofię tęczówki $[9,10]$, transiluminację $[9,10]$ oraz występowanie jakiś czas od zabiegu zapalenia przedniego odcinka błony naczyniowej oka [10-12]. W każdym opisywanym przypadku doszło do zaburzeń widzenia i do światłowstrętu [8-12].

Dotychczas nie opracowano protokołu leczenia przy użyciu laserów IPL. Po zabiegach, których liczba waha się od 1 do 3, obserwuje się znaczną poprawę funkcjonowania gruczołów Meiboma przez kilka miesięcy, poprawiają się również inne parametry, takie jak: test Schirmera, test przerwania filmu łzowego czy barwienie powierzchni oka fluoresceiną. Brak jest dużego opracowania określającego skuteczność tej metody w dłuższym okresie obserwacji.

Na koniec - trudno wyjaśnić dokładny mechanizm działania terapii IPL. Najbardziej rozpowszechnionym poglądem jest hipoteza upłynnienia złogów tłuszczowych wewnątrz gruczołów, co doprowadza do oczyszczenia przewodów wydzielniczych, a co za tym idzie - do poprawy jakości warstwy tłuszczowej filmu łzowego [6, 7].

Innymi możliwymi wyjaśnieniami poprawy stanu powierzchni oka po terapii IPL mogą być: koagulacja teleangiektazji naczyniowych w przestrzeni skóry powiek, a także okołoocznej, aktywacja fibroblastów do produkcji kolagenu, zmniejszenie ilości kolonizacji nużeńcem, modyfikacja kaskady zapalnej poprzez zmniejszenie wydzielania cytokin, takich jak: IL-4, IL-6, IL-10, IL-17A oraz TNF- $\alpha[6,13]$.

\section{ZABIEGI Z WYKORZYSTANIEM URZAZDZENIA LIPIFLOW ${ }^{\circledR}$ THERMAL PULSATION SYSTEM (WCZEŚNIEJ ABBOTT, OBECNIE JOHNSON \& JOHNSON)}

Urządzenie używa jednorazowych końcówek, składających się z osłony zakładanej bezpośrednio na gałkę oczną oraz części jednocześnie uciskającej powieki i dostarczającej ciepła. Technologię opatentowano pod nazwą Vector Thermal Pulsation (VTP). Zabieg trwa ok. 12 min i jest przeprowadzany w warunkach ambulatoryjnych.

Zasada działania sprowadza się do upłynnienia wydzieliny gruczołów Meiboma, a następnie dokładnego ich opróżnienia przy użyciu mechanicznej końcówki zakładanej na powieki.

Zgodnie z badaniami Blackie i wsp. [5], na grupie 200 pacjentów, poprawę wydzielania gruczołów powiekowych Meiboma uzyskano w 86\% przypadków po jednorazowym zabiegu, a efekt terapeutyczny utrzymywał się pomiędzy 5,4 a 17,3 miesiąca, średnio ok. 12 miesięcy.

$\mathrm{Z}$ badania zostali wykluczeni pacjenci, u których niewydolność gruczołów mogła mieć związek z przyjmowanymi lekami, ze schorzeniami ogólnymi, których trudno napotkać w codziennej praktyce klinicznej, stąd powyższe wyniki należy traktować z pewną ostrożnością.
Greiner [14] wykazał poprawę wyników testu przerwania filmu łzowego u 18 pacjentów poddanych terapii LipiFlow ${ }^{\oplus}$ Thermal Pulsation, wyjściowo $(4,9 \mathrm{~s} \pm 3,0 \mathrm{~s})$, po roku $(6,0 \mathrm{~s}$ $\pm 4,4$ s). Ten sam autor [15] w grupie 20 pacjentów nie wykazał utrzymującej się poprawy wyników testu przerwania filmu łzowego w dłuższym okresie - wyjściowo (4,1 s) po 3 latach $(4,5 \mathrm{~s})$.

Minusem urządzenia jest kontaktowy charakter terapii, mogący pociągać za sobą ryzyko uszkodzenia rogówki, a także zakażenia pomimo używania jednorazowych końcówek.

Dodatkowo cena zabiegu LipiFlow ${ }^{\odot}$ jest stosunkowo wysoka ze względu na konieczność stosowania jednorazowych końcówek do każdego zabiegu.

\section{KWANTOWY REZONANS KOMÓRKOWY}

Technologia wykorzystująca zjawisko biomolecular quantum resonance (BQR) nie ma jeszcze polskiej nazwy, przetłumaczyłem ją jako „kwantowy rezonans komórkowy” (KRK). Jako że nie jest to termin uznany ani powszechnie stosowany, w dalszej części artykułu będę go stosował w cudzysłowie, wymiennie z angielską nazwą.

Wyjaśniając nazwę - kwantowy oznacza „dostarczanie określonej dawki (kwantu) energii w danym przedziale czasowym”. Duża szybkość pulsów energii zapobiega przegrzaniu się tkanek. A rezonans komórkowy jest to wpływ zmiennej częstotliwości (4-64 MHz) energii elektromagnetycznej na funkcjonowanie komórek, głównie poprzez oddziaływanie na transport jonów przez błony komórkowe, a co za tym idzie - na połączenia międzykomórkowe. Należy podkreślić, że gdyby energia magnetyczna była dostarczana na stałe, a nie poprzez uwalnianie niewielkich dawek (kwantów) energii, to urządzenie działałoby na zasadzie kuchenki mikrofalowej i zamiast leczyć, doprowadzałoby do przegrzania tkanki, poprzez generowanie ciepła głównie z wody zawartej w komórkach.

Rezonans pomiędzy komórkami a falami generowanymi przez urządzenie najlepiej sobie wyobrazić na przykładzie szkła. Szklane przedmioty można rozbić poprzez wprowadzenie ich w rezonans dźwiękiem o odpowiednim natężeniu i częstotliwości, który wywołałby drgania wewnętrzne na tyle dużej amplitudy, że szkło by się rozpadło.

$\mathrm{Z}$ powyższego przykładu skorzystano, wykorzystując technologię "kwantowego rezonansu komórkowego" w chirurgii delikatnych organów, takich jak pęcherzyki płucne czy tkanka mózgowa [16, 17], gdzie szczególnie istotne jest precyzyjne cięcie bez przegrzewania operowanych tkanek.

Technologia KRK łączy w sobie zalety dwóch omówionych wcześniej metod (IPL, LipiFlow ${ }^{\oplus}$ ) dzięki generowanemu podczas zabiegu ciepłu. Pomaga ono w upłynnieniu złogów tłuszczowych zalegających w gruczołach 
Meiboma. Dodatkową zaletą tej metody jest możliwe wejście w interakcje na poziomie komórkowym $\mathrm{z}$ innymi gruczołami (łzowymi, Molla, Zeisa, Krausego, Wolfringa, Henlego i Manza, a także komórkami kubkowymi spojówki) uczestniczącymi w utrzymywaniu prawidłowego składu łez.

\section{DOŚWIADCZENIA WŁASNE}

Moje doświadczenia są skromne, ze względu na krótki okres obserwacji, nieprzekraczający 4 miesięcy, i niewielką grupę pacjentów.

Do zabiegu zakwalifikowano 20 pacjentów z zespołem suchego oka, 15 kobiet i 5 mężczyzn w wieku 59-85 lat (średnio 64 lata). Wszyscy pacjenci mieli potwierdzone rozpoznanie choroby suchego oka trwającej 5-20 lat (średnio 9,5 roku), średnia częstotliwość stosowania kropli nawilżających w ciągu dnia: 4 razy (maksymalnie 8 razy).

U 13 pacjentów (65\%) obecne były epiteliopatie w dolnej połowie rogówki obwodowej i pojedyncze w centrum, a także barwienie fluoresceiną spojówki nosowej i skroniowej odpowiadające stopniu 3 skali Oxford.

18 pacjentów ukończyło cykl czterech zabiegów powtarzanych w odstępie 7-10 dni. Dwóch pacjentów odbyło jedną sesję, a następnie nie zgłosiło się na dalsze leczenie, bez podania przyczyny. Zabiegi były wykonywane przy natężeniu 2-6 na skali aparatu, przeciętnie 3.
Trzech pacjentów odczuwało dyskomfort podczas sesji. Wyraźną subiektywną poprawę odczuło pięciu (27,7\%) pacjentów, pozostali nie zauważyli zmian w codziennym funkcjonowaniu.

Poprawę parametrów ocznych 3 miesiące od zabiegu, takich jak test przerwania filmu łzowego czy brak barwienia się rogówki fluoresceiną stwierdzono u siedmiu (38,9\%) pacjentów.

Powyższe wyniki są obiecujące, zważywszy na stopień zaawansowania objawów, a także długi czas trwania choroby. Praca nie została poddana analizie statystycznej ze względu na niewielką liczbę i brak randomizacji pacjentów.

\section{PODSUMOWANIE}

- Technika „kwantowego rezonansu komórkowego” wydaje się bezpieczna w stosowaniu, jedynym działaniem niepożądanym zgłaszanym przez pacjentów był dyskomfort związany z uczuciem za dużego ciepła podczas zabiegu.

- Zbadanie i wyjaśnienie oddziaływania pola elektromagnetycznego na wydzielanie łez pozostaje kwestią przyszłości.

- Przy założeniu, że możliwe jest pobudzenie wszystkich gruczołów oka do właściwej pracy, technika KRK mogłaby leczyć chorobę suchego oka w najbardziej kompleksowy sposób ze wszystkich dostępnych urządzeń, wymaga to jednak dodatkowych badań.

\section{ADRES DO KORESPONDENCJI dr n. med. Piotr Fryczkowski Przychodnia i Szpital Okulistyczny Retina 01-364 Warszawa, ul. Gimnazjalna 1 e-mail: p.fryczowski@retina.pl}

\section{Piśmiennictwo}

1. Gayton JL. Etiology, prevalence, and treatment of dry eye disease. Clin Ophthalmol. 2009; 3: 405-12.

2. Tah V, Saha K, Myerscough J et al. Dry eye - An Insight into Meibomian Gland Dysfunction. Ophthalmology - Current Clinical and Research Updates 2014; 7: 155-75.

3. Tomlinson A, Bron AJ, Korb DR et al. The International Workshop on Meibomian Gland Dysfunction: Report of the Diagnosis Subcommittee. Invest Ophthalmol Vis Sci. 2011; 52(4): 2006-49.

4. Craig JP, Tomlinson A. Importance of the lipid layer in human tear film stability and evaporation. Optom Vis Sci. 1997; 74: 8-13.

5. Blackie CA, Coleman CAE, Holland EJ. The sustained effect (12 months) of a single-dose vectored thermal pulsation procedure for meibomian gland dysfunction and evaporative dry eye. Clin Ophthalmol. 2016; 10: 1385-96.

6. Choi M, Han SJ, Ji YW et al. Meibum expressibility Improvement as a therapeutic target of Intense pulsed Light treatment in Meibomian Gland Dysfunction and Its Association with Tear Inflammatory Cytokines. Sci Rep. 2019; 9: 7648.

7. Xue AL, Wang MTM, Ormonde SE et al. Randomised double-masked placebo-controlled trial of the cumulative treatment efficacy profile of intense pulsed light therapy for meibomian gland dysfunction. Ocul Surf. 2020; article in press. 
8. Herbold TM, Busse H, Uhlig CE. Bilateral cataract and corectopia after laser eyebrow [corrected] epilation. Ophthalmology. 2005; 112(9): 1634-5.

9. Carrim ZI, Chohan AW, Devlin HC. Iris damage and acute pigment dispersion following photo-epilation. Eye. 2006; 20(12): 1486-8.

10. Elkin Z, Ranka MP, Kim ET et al. Iritis and iris atrophy after eyebrow epilation with alexandrite laser. Clin Ophthalmol. 2011; 5: 1733-5.

11. Halkiadakis I, Skouriotis S, Stefanaki C et al. Iris atrophy and posterior synechiae as a complication of eyebrow laser epilation. J Am Acad Dermatol. 2007; 57: S4-5.

12. Yalçındağ FN, Uzun A. Anterior uveitis associated with laser epilation of eyebrows. J Ophthalmic Inflamm Infect. 2013; 3: 45-8.

13. Liu R, Rong B, Tu P et al. Analysis of cytokine levels in tears and clinical correlations after intense pulsed light treating meibomian gland dysfunction. Am J Ophthalmol. 2017; 183: 81-90.

14. Greiner JV Long-term (12-month) improvement in meibomian gland function and reduced dry eye symptoms with a single thermal pulsation treatment. Clin Exp Ophthalmol. 2013; 41(6): 524-30.

15. Greiner JV Long-term ( 3 Year) Effects of a Single Thermal Pulsation System Treatment on Meibomian Gland Function and Dry Eye Symptoms. Eye Contact Lens. 2016; 42(2): 99-107.

16. Cherekaev VA, Bekiashev AKh et al. Experience in using a molecular resonance coagulator in neurooncology. Zh Vopr Neirokhir Im. N N Burdenko. 2005; (3): 33-6.

17. Kaku S, Ishii T, Hasegawa Y et al. Usefulness of Bipolar Forceps and Generator with High Frequency Technology for Point Coagulation and Tissue Adhesion. Curr Pract Neurosurg. 2008; 18(5): 617-24.

Konflikt interesów:

Nie występuje.

Finansowanie:

Nie występuje.

Etyka:

Treści przedstawione w artykule są zgodne z zasadami Deklaracji Helsińskiej,

dyrektywami EU oraz ujednoliconymi wymaganiami dla czasopism biomedycznych.
Conflict of interest:

None.

Financial support:

None.

Ethics:

The content presented in the article complies with the principles of the Helsinki Declaration, EU directives and harmonized requirements for biomedical journals. 